Juniper berries are said to be eaten readily by many animals, the seeds not being digested.'

The Mock Orange is a common and decorative shrub in the valleys east of the continental divide, but in Alberta it has so far been known only in the Waterton Lakes area, where it grows very sparsely on a few rock outcroppings on the southern slope of $\mathrm{Mt}$. Crandell near the townsite. It also grows luxuriantly in a small, eastfacing ravine just north of the former locality. In the summer of 1974 , a small colony of this shrub was discovered on the lower south-facing slopes of an unnamed ridge of red shale on the Alberta side of Mt.
Darrah, west of Pincher Creek. A specimen from this locality has been deposited at the University of Lethbridge Herbarium (Kuijt No. 4743). The similarity of the site to that of the first-mentioned Waterton site was striking. It seems entirely possible that other, comparable southern slopes between Mt. Darrah and Waterton Lakes will yield further specimens of this attractive shrub.

'HITCHCOCK, C. L., A. CRONQUIST, and M OWNBEY. 1969. Vascular plants of the Pacific Northwest. Vol. I. Univ. Washington Press Seattle.

"KUIJT, JOB. 1973. New plant records in Waterton Lakes National Park, Alberta. Can. Field-Nat. 87:67-69

"MOSS, E. H. 1959. Flora of Alberta. Univ Toronto Press.

\title{
TODAY'S WEEDS - TOMORROW'S VEGETABLES
}

\author{
by AL GRASS*
}

The other day I read an article in a garden magazine regarding "weeds" and it has prompted me to offer the following comments.

I would like to suggest that one man's weed is another man's wildflower. A weed, it seems, is a plant which competes with more "suitable" plant varieties. Should not a rose bush in a carrot patch be considered a weed? After all, it is stealing nutrients from the tasty carrot.

Some of our most beautiful wildflowers are weeds:

\section{"Fringing the stream at every turn \\ Swing low the waving fronds of fern; \\ From stoney cleft and mossy sod}

Pale asters spring and golden rod."
Every garden should have a weer patch. This has a dual purpose - te encourage small birds and insects to visit with you and so that you will have some weeds to study and admire. Wha better way to spend one's time than to cultivate dandelions for sparrows anc finches?

Have you ever thought that today' weeds may be tomorrow's vegetables We can imagine such tasty treats a creamed Stellaria on toast wedges an sweet pickled pigweed. Even today w can enjoy such treats as lamb's quar ters and dandelion greens.

Nothing is worse than a garde without weeds. Give me a weed patc anytime. There is a thousand-fol more to admire in weeds than in thei sickly pampered garden kin.

\footnotetext{
*From The Victoria Naturalist, 31(9) May, 1975.
} 